\title{
PECULIARITIES OF PREPARATION OF THE HACCP GROUP MEMBERS OF CATERING UNITS OF PRESCHOOL EDUCATIONAL INSTITUTIONS
}

\author{
Yevhenii Zhukov ${ }^{l}$, Roza Zorya ${ }^{2}$, Iryna Shelukhina ${ }^{3}$, Oleksandr Ashtaiev ${ }^{4}$ \\ ${ }^{1}$ Department of Food Technology, Hotel and Restaurant Business, Kharkiv College of Trade and Economics, Kyiv National University of \\ Trade and Economics, Kharkiv, Ukraine \\ yevheniizhukov@gmail.com \\ ORCID: https://orcid.org/0000-0002-8445-3490 \\ ${ }^{2}$ Department of Food Technology, Hotel and Restaurant Business, Kharkiv College of Trade and Economics, Kyiv National University of \\ Trade and Economics, Kharkiv, Ukraine \\ Zoryaroza@ukr.net \\ ORCID: https://orcid.org/0000-0002-6094-3540 \\ ${ }^{3}$ Department of Food Technology, Hotel and Restaurant Business, Kharkiv College of Trade and Economics, Kyiv National University of \\ Trade and Economics, Kharkiv, Ukraine \\ sheluhinairina@ukr.net \\ ORCID: https://orcid.org/0000-0001-6759-2045 \\ ${ }^{4}$ Department of Food Technology, Hotel and Restaurant Business, Kharkiv College of Trade and Economics, Kyiv National University of \\ Trade and Economics, Kharkiv, Ukraine \\ away198501011010@gmail.com \\ ORCID: https://orcid.org/0000-0002-4211-1521
}

ARTICLE INFO

Article history:

Received date 16.03.2021

Accepted date 20.04.202

Published date 30.04 .2021

Section

Organizational Behavior and Human Resource Management

DOI

$10.21303 / 2313-8416.2021 .001733$

KEYWORDS

HACCP group

preschool catering unit

non-formal education

National qualifications framework

\section{ABSTRACT}

The object of research: specific differences in the functioning of HACCP groups of catering units of preschool educational institutions, which determine the potential directions of training the personnel of such groups.

Investigated problem: training activities for HACCP teams and conformity assessment are guided by the practice of voluntary implementation and certification of food safety management systems. Although the introduction of permanent procedures based on the principles of the HACCP system at the facilities is a mandatory requirement, the current legislation does not provide for the certification of such procedures. Therefore, the adopted schemes for training specialists for food safety management systems require revision in order to harmonize with the national specifics of the implementation of HACCP procedures in the catering units of preschool education institutions.

Main scientific results: conclusions are drawn that can help maximize the success of the preparation of the HACCP group members for the catering units of preschool educational institutions:

1. Training of personnel for HACCP groups can be carried out by obtaining formal education with the help of existing educational programs after the implementation of appropriate educational components into them.

2. When developing educational components for training potential participants in HACCP groups, it is advisable to take into account that at least one participant must have more relevant competencies than is customary in the practice of creating HACCP groups at large and medium capacities.

3. The expected learning outcomes of the HACCP team members should provide opportunities for younger HACCP team members to feel confident that they are not "challenging their older colleagues" but providing valid explanations and evidence.

The field of practical application of the research results: the results obtained give an idea of the peculiarities of the functioning of the HACCP groups of the catering units of preschool education institutions. The established circumstances made it possible to identify the specific features of personnel training for participation in the HACCP group. Such information is useful for officials who make a decision to create a HACCP group in the catering unit of a preschool education institution, recruit it and develop a training program for its participants. Innovative technological product: approaches to the development of educational components of educational programs for training personnel of HACCP groups for the catering units of preschool education institutions, taking into account the investigated features of the functioning of such groups.

Scope of application of the innovative technological product: the established potential directions and restrictions in the training of personnel for participation in the HACCP group are relevant, understandable and aimed at officials who make the decision to create a HACCP group for the catering units of preschool education institutions, its staffing and the development of a training program for participants in this group. 


\section{Introduction}

\section{1. The object of research}

The object of the research is the specific differences in the functioning of the HACCP groups of catering units of preschool educational institutions, which determine the potential directions of training the personnel of such groups.

\section{2. Problem description}

Preschool catering facilities are facilities that are designed for the production and circulation of food products in the form of culinary products that are ready for direct consumption. Since such capacities are under the administration of preschool education institutions, these establishments are granted the status of operators of the food market. According to national requirements, food market operators are required to:

a) develop, implement and apply existing procedures based on the principles of the HACCP system;

b) provide the necessary training for workers to ensure the proper development, implementation and application of such procedures [1].

There are schemes for the training of personnel who are involved in the development, implementation and maintenance of food safety procedures. The study of such activities is reflected, for example, in works [2-6]. At the same time, the required level of personnel competence is achieved as a result of providing additional knowledge, skills and abilities to future participants of HACCP groups with an established certain level of already acquired professional (vocational) and/or higher education [2]. Also, the criterion for granting permission to study in the field of food safety is the presence of a certain work experience in the relevant field of food circulation or the field that provides such treatment [3]. The traditional type of education in such cases is non-formal adult education, but it is also possible to use informal education. Professional development takes place in the following types of training, such as trainings and seminars [4].

After training or advanced training of personnel, a food manufacturer can independently recognize the results of such education or use procedures for voluntary certification of personnel, as reflected in [5]. To assess the effectiveness of training and establish the compliance of personnel, it is advisable to use a specification matrix that describes the training objectives [6].

As can be seen from the above works, the existing procedures for training personnel for HACCP groups and conformity assessment are guided by the practice of voluntary application of the HACCP principles, as well as the voluntary implementation and certification of food safety management systems. Although the introduction of permanent procedures based on the principles of the HACCP system in the catering units of preschool education institutions is a mandatory requirement, the current legislation does not provide for their certification [7]. Therefore, the adopted schemes for training specialists for food safety management systems require validation and revision in order to harmonize with the national specifics of the implementation of HACCP procedures in the catering units of preschool education institutions.

\section{3. Suggested solution to the problem}

The identified problem can be solved by establishing the features of the functioning of HACCP groups at the catering units of preschool education institutions with the subsequent adjustment of the training schemes for participants in HACCP groups. Adjustment of educational programs should be related to such characteristics of employees as knowledge, skills and abilities. For this, it seems advisable to compare the known requirements for the training of personnel and their certification in non-formal education schemes [8] with typical staff standards of preschool education institutions [9], the National Classifier of Ukraine "Classifier of Occupations" [10] and the description of qualification levels of the National Qualifications Framework [11]. A related confirmation of this hypothesis is contained, for example, in [6], where Bloom's taxonomy was used to assess the suitability of learning outcomes in training participants in HACCP groups. The results of such a comparison with the subsequent generalization of the analytical information obtained can contribute to the development of recommendations for the design of relevant educational components and their introduction into educational (educational and professional) programs of formal education institutions of various levels of education. 
The aim of research: to study the possibility of training personnel of HACCP groups of catering units of preschool education institutions by obtaining formal vocational or higher education, clarifying the presence of strategic and tactical restrictions in the development of educational components of educational (educational and professional) training programs for potential participants in HACCP groups in order to obtain guaranteed confidence in reliable provided the established level of safety of culinary products, and justification for the development of the staff of HACCP groups in the required volume of program competencies and soft skills.

\section{Materials and methods}

Publicly available data from scientific sources, legal, by-laws and regulations, as well as registers of conformity assessment bodies were selected for the materials of a scientific study of the features of training participants in HACCP groups for catering units of preschool education institutions.

As methods of scientific knowledge, general scientific methods of systemic research were used, namely: collection of information, analysis, grouping, comparison, synthesis and generalization.

\section{Results}

\section{1. Functions of HACCP group members and qualifications}

The National Accreditation Agency of Ukraine allows certification of a number of qualifications in food safety management systems. Each of these qualifications is characterized by the requirements of basic education and special education, experience in the production, control and circulation of food products. At the same time, the following functional composition of the HACCP group is generally recognized: (a) group leader, (b) technical secretary of the group, (c) group member, (d) controller. Comparison of the functions of the members of the HACCP group and qualification levels is given in Table $\mathbf{1}$.

Table 1

The functional composition of the HACCP group and qualifications in food safety management systems

\begin{tabular}{cc}
\hline Persona function & Qualification name \\
\hline leader & Manager/Junior Manager of Food Safety Management Systems \\
technical secretary & Junior Manager/Food Safety Management Systems Manager \\
participant & Specialist/Junior Specialist of Food Safety Management Systems \\
controller & Internal auditor of food safety management systems
\end{tabular}

Sources: [2, 5]

\section{2. Stages of the process of organizing children's meals in preschool educational in-} stitutions

The process of organizing meals for children in preschool education institutions includes the following stages:

I) menu planning;

II) food planning;

III) entrance rejection;

IV) storing food items under controlled conditions;

V) process planning

VI) manufacturing of culinary products;

VII) rejection of finished culinary products;

VIII) distribution of finished culinary products into groups;

IX) transportation of finished culinary products to groups;

$\mathrm{X}$ ) process control;

$\mathrm{XI})$ maintaining good sanitary conditions;

XII) sanitation control.

\section{3. Established positions and functions in the HACCP group}

Comparisons of the staff positions of employees of preschool education institutions [9] and their role participation in the stages of the process of organizing children's nutrition with possible functions in the HACCP groups are given in Table 2. 
Table 2

Established positions of employees of preschool education institutions and functions of the HACCP group

\begin{tabular}{|c|c|c|}
\hline Person's position & Stages of the process of organizing children's meals & Functions in the HACCP group \\
\hline Director & Menu planning & team leader \\
\hline Nurse & $\begin{array}{c}\text { Menu planning } \\
\text { Food planning } \\
\text { Entrance rejection } \\
\text { Process control } \\
\text { Sanitary control } \\
\text { Rejection of finished culinary products }\end{array}$ & Team Leader/Technical Secretary \\
\hline Storekeeper & $\begin{array}{c}\text { Food planning } \\
\text { Entrance rejection } \\
\text { Storage of food supply facilities under controlled } \\
\text { conditions }\end{array}$ & $\begin{array}{c}\text { Technical Secretary/Team Member/ } \\
\text { Internal Auditor }\end{array}$ \\
\hline Chef & $\begin{array}{c}\text { Menu planning } \\
\text { Input rejection } \\
\text { Process planning } \\
\text { Manufacturing of culinary products } \\
\text { Process control } \\
\text { Rejection of finished culinary products } \\
\text { Delivery of finished culinary products to groups } \\
\text { Sanitary control }\end{array}$ & Group Member/Internal Auditor \\
\hline Cook & $\begin{array}{l}\text { Manufacturing of culinary products } \\
\text { Delivery of finished culinary products to groups }\end{array}$ & Group Member/Internal Auditor \\
\hline Auxiliary worker & Maintaining proper sanitary conditions & - \\
\hline Caregiver assistant & Transportation of finished culinary products to groups & Group Member/Internal Auditor \\
\hline
\end{tabular}

\section{4. Established positions and qualifications framework}

Information support in Ukraine in solving the problems of distributing personnel by professional groupings of different levels of classification, planning additional personnel needs, developing forecasts for education and retraining of personnel is provided by the National Classifier of Ukraine "Classifier of Occupations" [10]. Of great practical interest is the comparison of normative information from this source with the description of qualification levels of the National Qualifications Framework [11]. The results of this comparison are shown in Table 3.

Table 3

Established positions of employees of preschool education institutions and qualifications framework

\begin{tabular}{|c|c|c|c|}
\hline Person's position & Group of professions & Diploma qualification & Qualification level \\
\hline Director & Leaders & Bachelor Master & $6 / 7$ \\
\hline Nurse & Specialists & $\begin{array}{l}\text { Professional Junior Bachelor/ } \\
\text { Junior Bachelor/Bachelor }\end{array}$ & $5 / 6$ \\
\hline Storekeeper & The simplest professions & $\begin{array}{c}\text { Primary general education/ } \\
\text { basic general secondary } \\
\text { education }\end{array}$ & 1 \\
\hline Chef & Trade and service workers & $\begin{array}{l}\text { Complete general secondary } \\
\text { and vocational education/ } \\
\text { professional junior bachelor/ } \\
\text { junior bachelor }\end{array}$ & $4 / 5$ \\
\hline Cook & Trade and service workers & $\begin{array}{l}\text { Complete general secondary } \\
\text { and vocational education }\end{array}$ & $3 / 4$ \\
\hline Auxiliary worker & The simplest professions & $\begin{array}{c}\text { Primary general education/ } \\
\text { basic general secondary } \\
\text { education }\end{array}$ & 1 \\
\hline Caregiver assistant & Trade and service workers & $\begin{array}{l}\text { Complete general secondary } \\
\text { and vocational education }\end{array}$ & $3 / 4$ \\
\hline
\end{tabular}




\section{Discussion of results}

\section{1. Functions of HACCP group members and qualifications}

The scheme for comparing the function of a person in the HACCP group with the name of the qualification (Table 1), which can be used in assessing the conformity of personnel, has reliably proved itself for those capacities where there is a large staff of employees. In such conditions, the members of the HACCP group are carefully selected from a wide range of applicants according to the knowledge gained, professional skills and the acquired experience of profile activities. However, a significant difference between catering units at preschool educational institutions is that they belong to the category of "low power". Such facilities have the following classification characteristics: they (a) supply food to the end consumer, (b) have no more than ten workers, (c) occupy an area of no more than $400 \mathrm{~m}^{2}$ [1]. This circumstance with a high probability has a negative effect on the effective completing of the HACCP group with its members, since in fact only those workers who are available are involved in this group without any competitive selection. Such a phenomenon can inevitably lead to the loss of the interdisciplinary essence of the HACCP group. Meanwhile, the interdisciplinary nature of the HACCP group is considered a solid foundation for the development, implementation and maintenance of food safety management systems, since it has undoubtedly been proven that with a team approach, the established level of food safety is ensured much more reliably than with the individual activities of individual workers [12].

The expediency of developing specialized programs for the preparation of each HACCP group is proved, for example, in works $[4,13,14]$. Therefore, when developing educational components of educational (educational and professional) programs for the preparation of potential participants in HACCP groups for catering units at preschool educational institutions, it is advisable to plan that at least one participant should have more relevant competencies than is customary in the practice of creating HACCP groups at large and medium-sized capacities.

\section{2. Stages of the process of organizing children's meals in preschool educational in- stitutions}

The implementation of the principles of HACCP in catering establishments is a difficult task arising from such organizational circumstances as a wide range of culinary products manufactured and a variety of technological operations [15]. The identification of the stages of the process of organizing food for children in preschool educational institutions shows that catering units at preschool educational institutions work according to the "Cook \& Serve" scheme, which is inherent in most stationary institutions. However, at the same time, the consumption of rations itself is organized not in the trading floor of the catering establishment, but in group rooms. Therefore, the "Cook \& Serve" scheme is necessarily supplemented with the stage "transportation of finished culinary products into groups", which brings the activities of catering units at preschool educational institutions closer to the activities of restaurants on special orders (catering) [16].

It should be borne in mind that the current by-laws limit the time between the end of the technological process of cooking culinary products and the beginning of its use for a period of 30 minutes [17]. The established circumstances, obviously, make a significant impact on the distribution of functions in the HACCP groups, which are created at the catering units of preschool education institutions, in comparison with other facilities. Therefore, the learning outcomes of the HACCP group members should provide opportunities for building confidence that the established level of safety of culinary products is reliably ensured during transportation, and that the finished culinary products, after being transported outside the catering unit, will not cause harm to the health of consumers.

\section{3. Established positions and functions in the HACCP group}

The volume of participation of officials of preschool education institutions in the stages of the process of organizing children's meals, according to Table 2, is illustrated using Fig. 1. As can be seen from the above data, the chef and the nurse were involved in the largest number of stages (respectively, 8 and 6 stages, or $36 \%$ and $27 \%$ ). Persons holding the positions "Director", "Assistant to the teacher" and "Auxiliary worker" take part in one of the stages. However, it is common practice to appoint a director as the HACCP team leader. 
The members of the HACCP group, when performing their functional duties within the framework of the planned activities of the group, interact with each other through mutual exchange of knowledge and experience. Therefore, it is important to understand how the members of the HACCP group work together in making informed and balanced decisions about compliance with the established level of safety of finished culinary products.

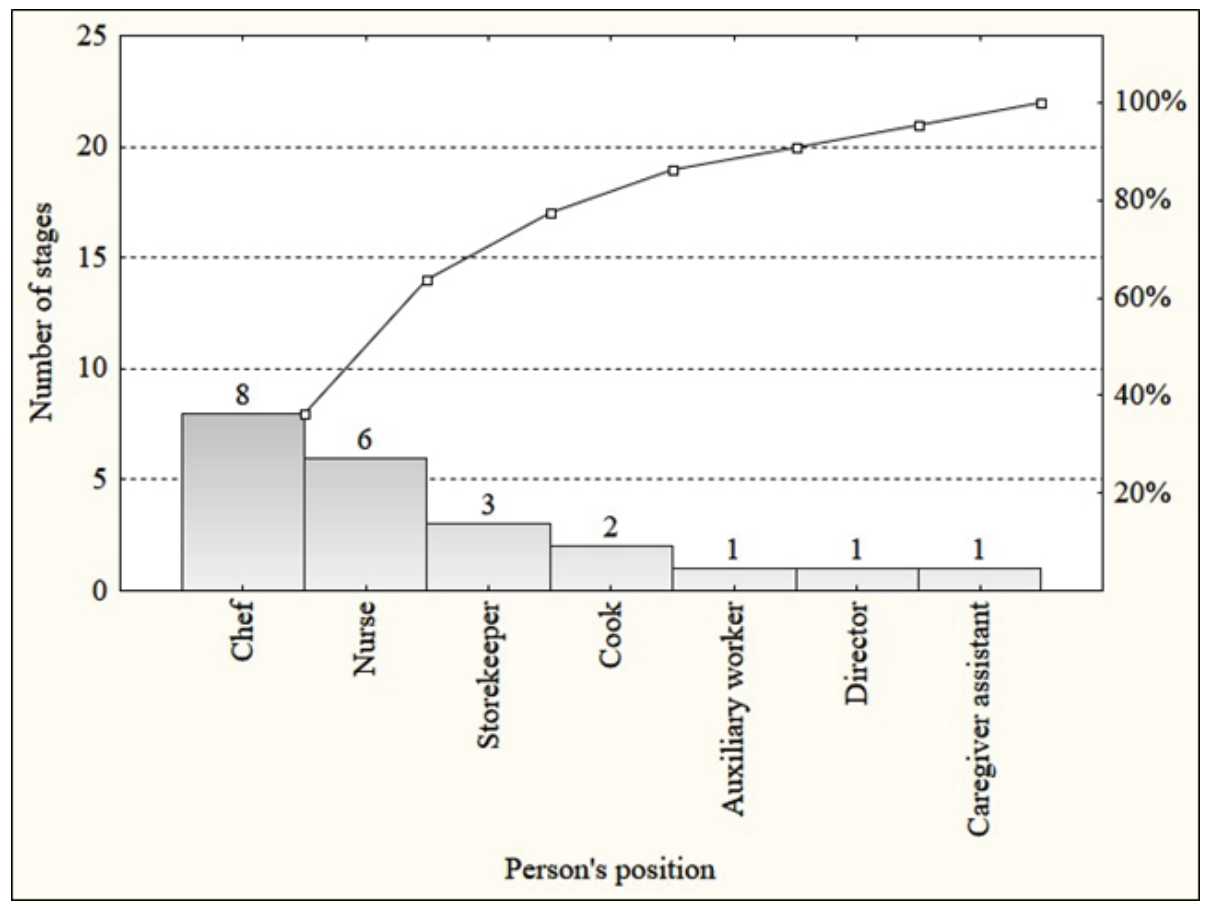

Fig. 1. Participation of officials in the stages of the process of organizing children's meals

Of course, the performance of higher business functions requires a large amount of knowledge and experience [18]. However, in conditions of the unmotivated influence of the authority of the position, especially on the younger members of the HACCP group, when there is a difference of opinion and the adoption of relevant decisions, an undesirable effect of reducing the safety level of finished culinary products is possible. That is why it is advisable to strive for the expected learning outcomes of the HACCP group members of catering units at preschool education institutions should provide opportunities for the formation of the younger members of the HACCP group confidence that they do not "challenge their older colleagues", but provide reasonable explanations and evidence.

\section{4. Established positions and qualifications framework}

Information, built in Table 3, shows that the distribution of positions by profession groups is as follows: managers and specialists - one position each, trade and service workers - three positions, the simplest professions - two positions. According to the National Qualifications Framework, the group of professions "managers" corresponds to a qualification according to the diploma "master" or "bachelor"; the group of professions "specialists" - "bachelor" or "junior bachelor" or "professional junior bachelor"; the group of professions "workers in the sphere of trade and services" - "junior bachelor" or "professional junior bachelor" education "; the group of professions "simple professions" - "basic general secondary education" or "primary general education". The mere implementation of a HACCP system does not guarantee that the market operator can achieve the specified level of food safety. In the real world, there are many examples of market operators having implemented a food safety management system at their facilities and failed to properly manage some of the hazards. In [19], it is shown that the level of education of the participants in HACCP groups has a significant impact on the performance of such important activities as identification of hazardous factors, assessment of hazardous factors and management of hazardous factors. Members of HACCP teams may unknowingly make mistakes 
in the use of hazard analysis tools and procedures. This is most likely due to the fact that the members of the HACCP groups do not have sufficient knowledge and/or experience in the use of such tools, as well as the development and implementation of such procedures [20]. The market operator can identify its strengths and weaknesses in food safety management and, based on strategic decisions, maximize strengths or minimize weaknesses in order to achieve or exceed a predetermined level of confidence in food safety.

The weak positions that pose difficulties for the HACCP group, according to [20], are the need for curricula, qualification standards and experience in this subject area. The standardization of qualification levels is done in the National Qualifications Framework. The application of its provisions regarding functions in the HACCP group is given in Table 4.

Table 4

Compliance of the functional composition of the HACCP group with the National Qualifications Framework

\begin{tabular}{|c|c|c|c|}
\hline $\begin{array}{l}\text { Persona } \\
\text { function }\end{array}$ & Description of qualifications & $\begin{array}{c}\text { Qualification } \\
\text { level }\end{array}$ & Educational level \\
\hline Leader & $\begin{array}{c}\text { Skills: solving complex specialized tasks and practical problems in the field of } \\
\text { professional activity } \\
\text { Communication: collecting, interpreting and applying data } \\
\text { Responsibility: managing complex technical or professional activities or } \\
\text { projects }\end{array}$ & 6 & Bachelor \\
\hline $\begin{array}{l}\text { Technical } \\
\text { secretary }\end{array}$ & $\begin{array}{l}\text { Skills: performing complex specialized tasks, finding or making decisions on } \\
\text { specific problems in the field of professional activity } \\
\text { Communication: implementation of mentoring, transfer of experience } \\
\text { Responsibility: self-organizing according to rules that exist in work contexts } \\
\text { and are usually predictable, but subject to change }\end{array}$ & 4 & $\begin{array}{l}\text { the third (higher) } \\
\text { level of profes- } \\
\text { sional (vocational) } \\
\quad \text { education }\end{array}$ \\
\hline Participant & $\begin{array}{l}\text { Skills: Performing routine tasks and solving problems by selecting and } \\
\text { applying basic methods, tools, materials and information } \\
\text { Communication: the ability to work effectively in a team } \\
\text { Responsibility: Responsibility for completing tasks while working }\end{array}$ & 3 & $\begin{array}{l}\text { the second (basic) } \\
\text { level of profes- } \\
\text { sional (vocational) } \\
\quad \text { education }\end{array}$ \\
\hline Controller & $\begin{array}{c}\text { Skills: assessing the results of tasks in accordance with predetermined criteria } \\
\text { Communication: the development of detailed oral and written messages in } \\
\text { professional activities } \\
\text { Responsibility: adapting one's behavior to external circumstances when per- } \\
\text { forming tasks or solving problems }\end{array}$ & 3 & $\begin{array}{l}\text { the second (basic) } \\
\text { level of profes- } \\
\text { sional (vocational) } \\
\quad \text { education }\end{array}$ \\
\hline
\end{tabular}

The information provided indicates that formal education provided by higher education institutions within the National Qualifications Framework has the potential to provide training for HACCP team members for preschool catering units. At the same time, the head of the HACCP group can obtain the necessary competencies in the first cycle of higher education, the technical secretary of the group - at the third (highest) level of professional (vocational) education, other group members and controllers (internal auditors) - at the second (basic) level of professional (vocational) education.

Thus, the training of personnel for HACCP groups of catering units of preschool education institutions can be carried out not only as a result of seminars and trainings for workers [21], but also by obtaining education with the help of existing educational (educational and professional) programs after introducing appropriate educational components into them.

The limitation of this study is manifested in the absence of reliable statistical information on the quality level of training of employees of preschool education institutions, which are generally accepted to be included in the HACCP groups on the issues of food commodity science, the technology of manufacturing culinary products for feeding children's contingents, organizing the production and service of children's contingents, hygiene and sanitation of the catering units of preschool education institutions.

Prospects for the further development of the obtained results are seen in the study of the needs or expectations of the stakeholders of the HACCP groups of the preschool educational in- 
stitutions for the preparation of participants in such groups and the formulation of these goals or expectations in the characteristics of learning outcomes according to Bloom's taxonomy.

\section{Conclusions}

1. Training of personnel for HACCP groups of catering units of preschool education institutions can be carried out by obtaining formal vocational or higher education with the help of existing educational (educational and professional) programs after the introduction of appropriate educational components into them.

2. When developing educational components of educational (educational and professional) programs for the preparation of potential participants in HACCP groups of catering units at preschool educational institutions, it is advisable to take into account that at least one participant must have more relevant competencies than is customary in the practice of creating HACCP groups in large and medium capacities.

3. The results of the formal education of the HACCP group members should provide opportunities for building confidence that the established level of safety of culinary products is reliably ensured during their transportation from the catering unit to the premises of the group cells, and that the finished culinary products, after being transported outside the catering unit, should not harm to the health of consumers.

4. Expected learning outcomes for HACCP group members in preschool education should provide opportunities for younger HACCP group members to feel confident that they are not "challenging their older colleagues" but provide valid explanations and evidence.

This study gives an idea of the peculiarities of the functioning of HACCP groups, which are created for the catering units of preschool education institutions. It identifies potential directions and limitations in training personnel for participation in a HACCP group, which should be understandable to officials who decide to create a HACCP group, its recruitment and the development of a training program for its members.

\section{References}

[1] Pro osnovni pryntsypy ta vymohy do bezpechnosti ta yakosti kharchovykh produktiv (1997). Zakon Ukrainy No. 771/97/VR. 23.12.1997. Available at: http://zakon5.rada.gov.ua/laws/show/771/97-вр

[2] Zhukov, Ye. V., Yahodzinskyi, D. A. (2005). Osoblyvosti pidhotovky fakhivtsiv systemy upravlinnia bezpechnistiu kharchovykh produktiv. Svit yakosti Ukrainy, 2, 46-48.

[3] Artemenko, V. S., Zhukov, Ye. V. (2008). Planuvannia Systemy upravlinnia bezpechnistiu kharchovykh produktiv: pidhotovka kerivnyka hrupy bezpechnosti. Kharkiv: KhTEI KNTEU, 152-153.

[4] Vukman, D., Viličnik, P., Vahčić, N., Lasić, D., Niseteo, T., Krbavčić, I. P. et. al. (2020). Design and evaluation of an HACCP gluten-free protocol in a children's hospital. Food Control, 120, 107527. doi: http://doi.org/10.1016/j.foodcont.2020.107527

[5] Kabakov, Yu. B. (2016). Akredytovani orhany sertyfikatsii personalu. Sumy: SDU, 284-285.

[6] Azanza, M. P. V., dela Paz, C. J. E. (2007). Learning HACCP in Philippine lingua franca. Food Control, 18 (12), $1524-1531$. doi: http://doi.org/10.1016/j.foodcont.2006.12.004

[7] Pro zatverdzhennia metodychnykh nastanov shchodo rozroblennia, zaprovadzhennia ta vykorystannia postiino diiuchykh protsedur, yaki bazuiutsia na pryntsypakh systemy analizu nebezpechnykh faktoriv ta kontroliu u krytychnykh tochkakh $\mathrm{v}$ zakladakh osvity (2020). Nakaz Minekonomiky Ukrainy No. 2374. 17.11.2020. Available at: https://bit.ly/35LCiRf

[8] Reiestr akredytovanykh orhaniv otsiniuvannia vidpovidnosti (2021). Natsionalne ahentstvo z akredytatsii Ukrainy. Available at: https://naau.org.ua/reyestr-akreditovanix-oov/

[9] Pro zatverdzhennia Typovykh shtatnykh normatyviv doshkilnykh navchalnykh zakladiv (2010). Nakaz MON Ukrainy No. 1055. 04.11.2010. Available at: https://zakon.rada.gov.ua/laws/show/z1157-10\#Text

[10] Klasyfikator profesii DK 003:2010 (2010). Nakaz vid Derzhspozhyvstandarty Ukrainy No. 327. 28.07.2010. Available at: https://zakon.rada.gov.ua/rada/show/va327609-10\#Text

[11] Pro zatverdzhennia Natsionalnoi ramky kvalifikatsii (2011). Postanova Kabinety Ministriv Ukrainy No. 1341. 23.11.2011. Available at: https://zakon.rada.gov.ua/laws/show/1341-2011-ח

[12] Wallace, C. A., Holyoak, L., Powell, S. C., Dykes, F. C. (2012). Re-thinking the HACCP team: An investigation into HACCP team knowledge and decision-making for successful HACCP development. Food Research International, 47 (2), 236-245. doi: http://doi.org/10.1016/j.foodres.2011.06.033

[13] Barone, N. A., Dicaprio, E., Snyder, A. B. (2020). A preliminary assessment of food safety training needs and preferences among Ohio food processors of various sizes. Food Control, 114 (2020), 107220. doi: http://doi.org/10.1016/j.foodcont.2020.107220 
[14] Tuncer, A., Akoğlu, A. (2020). Food safety knowledge of food handlers working in hotel kitchens in Turkey. Food and Health, 6 (2), 77-89. doi: http://doi.org/10.3153/fh20009

[15] Petrovskaya, I., Mital, O., Mital, S. (2020). Implementation of haccp system in fast food establishments. State and regions. Series: Economics and Business, 1 (112), 119-124. doi: http://doi.org/10.32840/1814-1161/2020-1-20

[16] Kyrnis, N. (2019). Main aspects of the HACCP system for catering companies. Cherkasy University Bulletin: Economics Sciences, 4, 214-220. doi: http://doi.org/10.31651/2076-5843-2019-4-214-220

[17] Pro zatverdzhennia Instruktsii z orhanizatsii kharchuvannia ditei u doshkilnykh navchalnykh zakladakh (2013). Nakaz MON Ukrainy \& MOZ Ukrainy. No. 298/227. 17.04.2006. Available at: https://zakon.rada.gov.ua/laws/show/z0523-06

[18] Gajda, R., Jeżewska-Zychowicz, M. (2012). HACCP system in food service sector - employees' knowledge of implementation of its rules exemplified by świętokrzyskie region. Zywnosc. Nauka. Technologia. Jakosc, 1 (80), 206-217. doi: http://doi. org/10.15193/zntj/2012/80/206-217

[19] Kafetzopoulos, D. P., Psomas, E. L., Kafetzopoulos, P. D. (2013). Measuring the effectiveness of the HACCP Food Safety Management System. Food Control, 33 (2), 505-513. doi: http://doi.org/10.1016/j.foodcont.2013.03.044

[20] Wallace, C. A., Holyoak, L., Powell, S. C., Dykes, F. C. (2014). HACCP - The difficulty with Hazard Analysis. Food Control, 35 (1), 233-240. doi: http://doi.org/10.1016/j.foodcont.2013.07.012

[21] Wandolo, D. M. A. (2019). Awareness on Hazard Analysis and Critical Control Points (HACCP) Principles in TVET and University Hospitality Schools in Kenya. International Journal of Scientific Research and Management, 7 (5), 174-188. doi: http:// doi.org/10.18535/ijsrm/v7i5.mp02 